\title{
Hørselshemmet blant hørende
}

Hørselshemmede og voksne døve beveger seg mellom to kulturer: den hørende kulturen som de vokser opp i, og døve- og tunghørtkulturen, som de etter hvert søker tilhørighet til.

Tunghørtes individualitet er forskjellig fra døv identitet, fordi døve primært bruker tegnspråk og har en forankring i døves identitet og kultur. Den israelske forskeren Tova Most har beskrevet personer med en døv identitet slik: de føler seg som en del av døvekulturen, aksepterer seg selv som døv og kommuniserer gjennom tegnspråk (1). For tunghørte er teknisk hjelpemidler, slik som høreapparat og cochleaimplantat, viktigere enn for døve, og det kan være viktigere for tunghørte å være sosiale deltakere i den hørendes verden.

Effektiv kommunikasjon, altså sosial kontakt og overføring av informasjon med andre mennesker, er et grunnleggende behov også for mennesker med døvhet og hørselshemning. Selv er jeg født med et sensorialt hørselstap. I 2003 fikk jeg operert inn et cochleaimplantat, som er et medisinsk hjelpemiddel. Cochleaimplantat kan også kalles et effektivt kommunikasjonsmiddel på linje med tegnspråktolk og tegnstøtte. Implantatet kan bidra til bedre sosial hørsel og økt livskvalitet og gi muligheten til å utvikle talekommunikasjonen. For pasienter med cochleaimplantat er det vanlig å si at de er tunghørte og ikke hørende.

Studier innen medisinsk og sosialpsykologisk forskning konkluderer likevel med at døve i større grad enn tunghørte aksepterer sin funksjonshemning. Mange døve har altså funnet sin personlige identitet. For mange med hørselstap kan identitetsutviklingen og kommunikasjonen med andre bli problematisk. Det å sammenlikne seg med andre mennesker som hører, kan være vanskelig - man vet ikke riktig hvem man er hørende eller døv - eller hvilken gruppe man tilhører.

Det er viktig at helsepersonell snakker med den døve og den tunghørte om forskjellen i døves identitet og tunghørtes individualitet. Hva tenker pasienten når han eller hun hører ordet hørselshemmede? Hva tenker pasienten om døve, tunghørte og hørende? Helsepersonell bør spørre dem som ikke aksepterer at de er døve eller tunghørte, om de blir lei seg når de hører ordet døv eller tunghørt? Mange vil kanskje si: Jeg vil være hørende - jeg vil ikke være døv som i dag. Da bør helsepersonell tre inn med støtte, omsorg og respekt for den døve eller tunghørtes situasjon for å finne ut svaret på spørsmålet: Hvem er jeg, egentlig?

\section{Merete Telstø \\ miamte@online.no}

Merete Telstø (f. 1963) har jobbet med kulturformidling for hørselshemmede i regi av Kulturdepartementet.

Forfatter har fylt ut ICMJE-skjemaet og oppgir ingen interessekonflikter.

Litteratur

1. Most T, Wiesel A, Blitzer T. Identity and attitudes towards cochlear implants among deaf and hard of hearing adolescents. Deafness Educ Int 2007; 9 68-82.

Mottatt 27.4. 2012, første revisjon innsendt 22.5. 2012, godkjent 21.6. 2012. Medisinsk redaktør Petter Gjersvik.

\section{Felleskatalogen for iPad Gratis tilgjengelig i App Store}

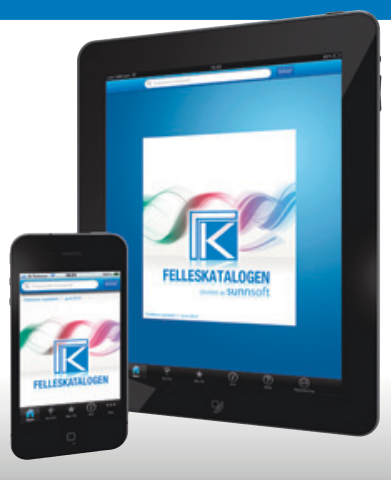

